\title{
The Facile Synthesis of Novel ZnO Nanostructure for Galactose Biosensor Application
}

\author{
Phuong Ha La Phan, ${ }^{1}$ Quang Trung Tran ${ }^{1},{ }^{1}$ Duc Anh Dinh, ${ }^{2}$ Ko Kang Bok, ${ }^{2,3}$ \\ Chang-Hee Hong, ${ }^{3}$ and Tran Viet Cuong ${ }^{2,3}$ \\ ${ }^{1}$ Department of Solid State Physics, University of Science, Vietnam National University-Ho Chi Minh City (VNU-HCM), 227 Nguyen \\ Van Cu, Ward 4, District 5, Ho Chi Minh City, Vietnam \\ ${ }^{2}$ NTT Hi-Tech Institute, Nguyen Tat Thanh University, 298-300 A Nguyen Tat Thanh Street, Ho Chi Minh City, Vietnam \\ ${ }^{3}$ LED Agri-Bio Fusion Technology Research Center, Chonbuk National University, Jeonju 561-853, Republic of Korea
}

Correspondence should be addressed to Quang Trung Tran; tqtrung@hcmus.edu.vn and Tran Viet Cuong; tvcuong@ntt.edu.vn

Received 18 October 2018; Accepted 20 December 2018; Published 25 February 2019

Academic Editor: Surinder Singh

Copyright (c) 2019 Phuong Ha La Phan et al. This is an open access article distributed under the Creative Commons Attribution License, which permits unrestricted use, distribution, and reproduction in any medium, provided the original work is properly cited.

\begin{abstract}
We introduce a novel structure of $\mathrm{ZnO}$ nanorods (NRs) grown on $\mathrm{ZnO} \mathrm{NRs}$ ( $\mathrm{ZnO}$ NRs/NRs) via a facile, low-cost, and environmentally friendly synthesis for galactose biosensor application. The galactose oxidase enzyme $\left(\mathrm{GalO}_{\mathrm{x}}\right)$ is immobilized on the $\mathrm{ZnO} \mathrm{NR} / \mathrm{NR}$ surface to form the novel electrode structure $\left(\mathrm{GalO}_{\mathrm{x}} \mid \mathrm{ZnO} \mathrm{NR} / \mathrm{NRs}\right)$. The $\mathrm{GalO}_{\mathrm{x}} \mid \mathrm{ZnO} \mathrm{NR} / \mathrm{NR}$ electrode has a linear detection range of current density from $11.30 \mu \mathrm{A} / \mathrm{mm}^{2}$ to $18.16 \mu \mathrm{A} / \mathrm{mm}^{2}$ over a galactose concentration range from $40 \mathrm{mM}$ to $230 \mathrm{mM}$, indicating the increment of electrode sensitivity up to $60.7 \%$. The ZnO NR/NR morphology with a high surface area to volume ratio has a great contribution to the electrochemical performance of galactose biosensor. Our results propose a straightforward approach to fabricate architecturally $\mathrm{ZnO}$-based nanostructure for biosensor application.
\end{abstract}

\section{Introduction}

Galactose (Gal), a common monosaccharide, is an important energy resource in living organisms [1]. Gal in the human body can be converted into glucose, which is the primary fuel for cellular energy production. The metabolism of $\mathrm{Gal}$ is based on the hydrolysis of lactose, which involves the significant contribution of various types of enzymes such as galactokinase, galactose-1-phosphate uridylic transferase, beta-galactoside, and galactose-6-phosphate epimerase [2]. However, the metabolism of Gal can cause the detrimental effect to the human body, so-called galactosemia, when the amount of one of the enzymes is insufficient [3]. The galactosemia is an inherited disorder that affects how our body processes $\mathrm{Gal}$, and the symptoms of galactosemia result from an inability to use Gal to produce energy [4]. For instance, a high level of Gal in infant bodies $(>1.1 \mathrm{mM})$ may develop cataracts, liver diseases, and kidney problems [5]. Even with medical treatment, children may suffer from learning disabilities, and females with galactosemia may have problems with their ovaries $[5,6]$. In the most serious case, the build-up of Gal can be very dangerous to the brain, leading to death [7]. Therefore, the quantitative determination and control of the Gal level in the human body, food, or dairy products are extremely important. So far, the most common method for the Gal analysis is the enzyme-based techniques using two types of enzymes: galactose oxidase $\left(\mathrm{GalO}_{\mathrm{x}}\right)$ or galactose dehydrogenase $(\mathrm{GADH})$, in association with spectrophotometric, polarimetric, and fluorometric detection of enzymatic products $[8,9]$. The GADH technique has been developed and commercialized; however, it is still expensive, time-consuming, and inconvenient (requires skilled personnel to operate them) [8-10]. Thus, electrochemical measurements, especially in conjunction with the use of amperometric biosensors based on $\mathrm{GalO}_{\mathrm{x}}$, are becoming more attractive for Gal analysis [11]. Such biosensors 
utilize the capability of $\mathrm{GalO}_{\mathrm{x}}$ to catalyze $\mathrm{Gal}$, as described by the following equations:

$$
D \text { - galactose }+\mathrm{O}_{2} \rightarrow{ }^{\text {GalO }} \times \text { } D-\text { galactohexodialdose }+\mathrm{H}_{2} \mathrm{O}_{2}
$$

$$
\mathrm{H}_{2} \mathrm{O}_{2} \rightarrow \mathrm{O}_{2}+2 \mathrm{H}^{+}+2 \mathrm{e}^{-}
$$

The electrochemical monitoring of the enzymatically produced $\mathrm{H}_{2} \mathrm{O}_{2}$ provides the analytical response. In fact, the electron transfer of the reaction of $\mathrm{H}_{2} \mathrm{O}_{2}$ can be detected easily even at low potentials, providing the signal of current in electrochemical measurement [11]. These anodic and cathodic currents are directly proportional to the amount of $\mathrm{Gal}[12,13]$. These aspects of $\mathrm{GalO}_{\mathrm{x}}$-based electrochemical biosensors would allow for the development of rapid, highly selective, sensitive, and low-cost analytical devices. The key feature of such biosensors is properties of electrode materials which allow the effective immobilization of the $\mathrm{GalO}_{\mathrm{x}}$ enzyme, one of the best catalytic agents for Gal [14]. In recent years, many efforts have been focused on the development of metallic nanoparticle(NP-) based Gal biosensor, e.g., gold NPs, due to their good conductivity, electrocatalytic ability, biocompatibility, and availability of many active sites [15-17]. However, these NPs are very easy to be aggregated, inducing the deterioration of their outstanding properties and instability of $\mathrm{GalO}_{\mathrm{x}}$ immobilization $[18,19]$. Another choice of electrode material is the use of cross-linking polymers, forming the three-dimensional network to entrap $\mathrm{GalO}_{\mathrm{x}}$ [20-22]. The use of synthetic polymers such as polyurethane, polyacrylamide, polyvinylchloride, polyvinyl alcohol, and polyvinyl formal (PVF) provides several advantages such as chemical resistance, high mechanical strength, and the feasible combination with buffer components [23, 24]. However, most of the disadvantages of these polymers are their poor conductivity, hindering the direct electron transfer (DET) between an enzyme and electrode. The disadvantages of NPs and polymers turn out that the proper materials for Gal biosensor must possess the proper physical/chemical properties and structure to guarantee not only the enzyme immobilization but also the DET process. In this context, $\mathrm{ZnO}$ has been recognized as a promising electrode material for Gal biosensor due to its interesting properties such as good chemical stability, good electron transport, nontoxic, high biological compatibility, and high isoelectric point (IP 9.5) [25-27]. In terms of material design, $\mathrm{ZnO}$ can be available in a variety of nanostructures such as nanowires, nanorods, and nanotubes which can be grown at the low temperature via the solution method [28]. Among these nanostructures, $\mathrm{ZnO}$ nanorod (NR) has shown numerous applications in the fields of bioelectronics because its high surface area to volume ratios allow great combination with immobilized enzymes [14, 29, 30]. Moreover, $\mathrm{ZnO}$ can maintain the activity of the enzyme due to the high biocompatibility and enhance the DET between the enzyme's active sites and the electrode. Also, the high IP of $\mathrm{ZnO}$ (9.5) makes it a good matrix to immobilize low isoelectric point enzymes, e.g., $\mathrm{GalO}_{\mathrm{x}}$ (4.61), by electrostatic interactions with high binding stability $[31,32]$.

Herein, we fabricate a novel nanostructure of $\mathrm{ZnO}$ NRs grown on $\mathrm{ZnO} \mathrm{NRs}$ ( $\mathrm{ZnO} \mathrm{NRs/NRs)} \mathrm{using} \mathrm{the} \mathrm{solution}$ method. The produced nanostructure demonstrates a significant increase in surface area to volume ratio with respect to that of $\mathrm{ZnO}$ NRs only, for Gal biosensor. Furthermore, $\mathrm{GalO}_{\mathrm{x}}$ is successfully immobilized in the ZnO NRs/NRs by using glutaraldehyde as a cross-linker. The effect of the morphologies of the $\mathrm{ZnO}$ nanocrystals on the $\mathrm{GalO}_{\mathrm{x}}$ immobilization applied in Gal biosensor is systematically studied. Our result is opening a new strategy to synthesize the novel $\mathrm{ZnO}$ nanostructure based on a facile, low-cost, and eco-friendly method for Gal biosensor application.

\section{Experimental}

2.1. Reagents and Materials. For synthesis of $\mathrm{ZnO} N R s$, zinc acetate dihydrate $\mathrm{Zn}\left(\mathrm{CH}_{3} \mathrm{COO}\right)_{2} \cdot 2 \mathrm{H}_{2} \mathrm{O}$, ethanol $\mathrm{C}_{2} \mathrm{H}_{5} \mathrm{OH}$, and monoethanolamine $\mathrm{NH}_{2} \mathrm{CH}_{2} \mathrm{CH}_{2} \mathrm{OH}$ are purchased from Merck, Germany. Acetone $\mathrm{C}_{3} \mathrm{H}_{6} \mathrm{O}$ is obtained from QREC, Malaysia. The phosphate buffered saline $(\mathrm{pH}=7.4)$ is purchased from HiMedia, India. Glutaraldehyde $\mathrm{C}_{5} \mathrm{H}_{8} \mathrm{O}_{2}$ is purchased from Merck, and galactose oxidase (lyophilizes powder $\geq 3000$ units/g solid) was from Sigma-Aldrich.

\subsection{The Growth of ZnO NRs and ZnO NRs/NRs on FTO} Substrate. Reagent grade (RG) zinc acetate dihydrate and monoethanolamine (MEA) were first dissolved in an ethanol solvent with a $\mathrm{Zn}^{2+}$ concentration of $0.75 \mathrm{M}$ to form a seed solution. This solution was magnetically stirred at room temperature for 2 hours. Fluorine doped tin oxide (FTO) substrate was coated with the seed solution by using a spin coating and then annealed at $500^{\circ} \mathrm{C}$ to form a $\mathrm{ZnO}$ seed layer. The size (area) of the FTO substrate is $1.2 \mathrm{~cm}^{2}$.

The $\mathrm{ZnO}$ NRs and $\mathrm{ZnO}$ NRs/NRs were fabricated from seed $\mathrm{ZnO}$-coated FTO substrate. The $\mathrm{ZnO}$ NRs were used as a reference to evaluate the effect of $\mathrm{ZnO} N \mathrm{NP} / \mathrm{NR}$ morphology on the performance of Gal biosensor. In detail, precursor zinc nitrate dehydrates $\left(\mathrm{Zn}\left(\mathrm{NO}_{3}\right)_{2} \cdot 2 \mathrm{H}_{2} \mathrm{O}\right)$ and hexamethylenetetramine (HMTA, $\mathrm{C}_{6} \mathrm{H}_{12} \mathrm{~N}_{4}$ ) were dissolved in an aqueous solution with a $\mathrm{Zn}^{2+}$ concentration of $0.02 \mathrm{M}$. This solution was stirred at room temperature for 2 hours. After that, the prepared $\mathrm{ZnO}$ seed layer on FTO substrate was dipped in that solution and kept in an oven at $80^{\circ} \mathrm{C}$ for 2 hours to form $\mathrm{ZnO}$ NRs. To synthesize $\mathrm{ZnO}$ $\mathrm{NRs} / \mathrm{NRs}$, the FTO-coated $\mathrm{ZnO}$ seed layer was dipped in above solution for 5 hours at $80^{\circ} \mathrm{C}$ to form large $\mathrm{ZnO}$ $\mathrm{NRs}$; the small $\mathrm{ZnO}$ NRs were subsequently grown at $80^{\circ} \mathrm{C}$ for 2 hours. Finally, products are rinsed with water and dried in an argon stream.

2.3. The Immobilization of the Galactose Oxidase Enzyme on $\mathrm{ZnO}$ Nanostructures. The $2.5 \%$ glutaraldehyde (GA) in $0.1 \mathrm{mM}$ phosphate buffer solution (PBS) and $\mathrm{GalO}_{\mathrm{x}}$ solution in PBS having a concentration of $2 \mathrm{mg} / \mathrm{mL}$ of enzyme are mixed in one bottle, then $\mathrm{ZnO}$ substrate is dipped into it in 3.5 hours at room temperature to examine the saturation 


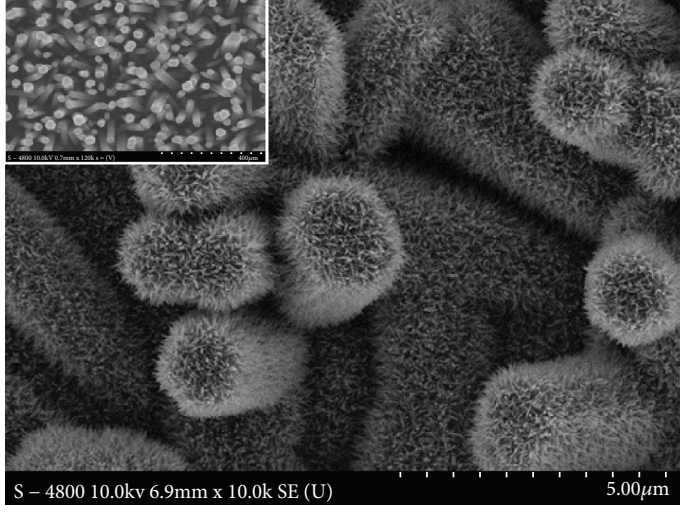

(a)

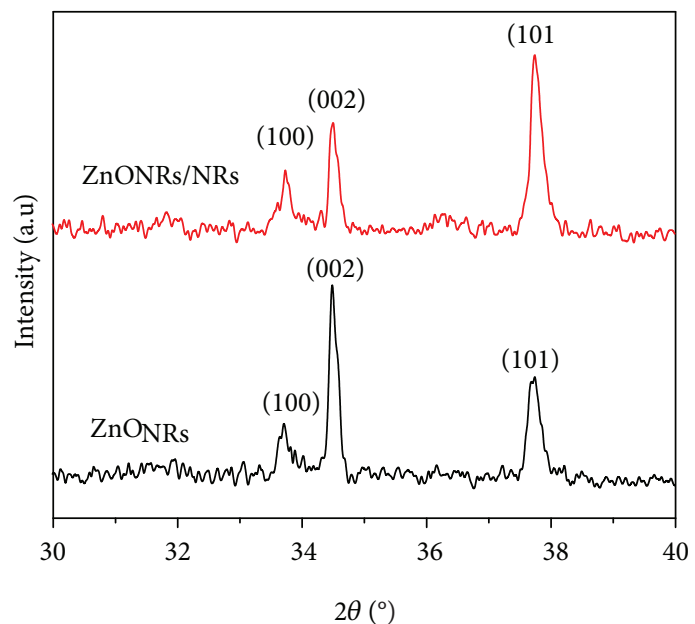

(b)

FIgure 1: (a) Scanning electron microscope and (b) X-ray diffraction patterns of RD of ZnO NRs and ZnO NRs/NRs.

of the $\mathrm{ZnO}$ surface with the $\mathrm{GalO}_{\mathrm{x}}$ enzyme immobilized $\mathrm{ZnO}$ electrode $\left(\mathrm{GalO}_{\mathrm{x}} \mid \mathrm{ZnO}\right)$.

2.4. Characterization. The $\mathrm{ZnO}$ NR samples were characterized by X-ray diffraction spectrometer (XRD) D8 Bruker with $\mathrm{Cu} \mathrm{K} \alpha$ radiation source $(\lambda=1.5417 \AA), 2 \theta$ range 30 $40^{\circ}, 0.03^{\circ}$ step size, and scanning speed $=12^{\circ} / \mathrm{min}$. The surface morphology of ZnO NRs and ZnO NR/NR samples was investigated by FE-SEM S4800-Hitachi at the voltage of $10 \mathrm{kV}$.

The optical absorption spectra (OAS) of $\mathrm{GalO}_{\mathrm{x}}$ enzyme solution after the immobilization on $\mathrm{ZnO}$ NRs were measured by UV-Vis spectroscopy U2910, Hitachi, Japan $(\lambda=450-700 \mathrm{~nm})$.

The FTIR spectroscopy of ZnO NRs and ZnO NR/NR samples after and before $\mathrm{GalO}_{\mathrm{x}}$ enzyme immobilization was carried out by an FTIR spectrophotometer JASCO-4700, Japan (wavenumber range $500-3500 \mathrm{~cm}^{-1}$ ).

The electrochemical properties of the proposed Gal biosensor based on the $\mathrm{GalO}_{\mathrm{x}}$ immobilized $\mathrm{ZnO}$ NRs and $\mathrm{ZnO}$ NR/NR electrode in Gal solution ( $200 \mathrm{mM}$ ) were measured by the cyclic voltammetry (CV) method with the MPG-2 analyzer (Bio-Logic), using $\mathrm{GalO}_{\mathrm{x}} \mid \mathrm{ZnO}$ NRs and $\mathrm{GalO}_{\mathrm{x}} \mid \mathrm{ZnO}$ NRs/NRs as a working electrode, a platinum plate as the counter electrode, and an $\mathrm{Ag} / \mathrm{AgCl}$ electrode as the reference one. Then the measurement was carried out at a scan rate of $100 \mathrm{mV} / \mathrm{s}$ with the potential range from $-0.5 \mathrm{~V}$ to $1.0 \mathrm{~V}$.

\section{Results and Discussion}

3.1. Structure and Morphology of $\mathrm{ZnO}$ Nanostructures. In this work, the $\mathrm{ZnO} \mathrm{NR} / \mathrm{NR}$ structure is grown by means of the solution method which has the advantages of simplicity, low-cost, and environment-friendliness. The surface morphology of $\mathrm{ZnO}$ and $\mathrm{ZnO}$ NRs/NRs is examined by SEM. Figure 1(a) depicts SEM micrograph of ZnO NRs/NRs; the inset showing the morphology of $\mathrm{ZnO}$ NRs only. The SEM images of $\mathrm{ZnO}$ NRs show the hexagonal structure of these NRs with the higher vertical alignment on $\mathrm{ZnO}$ seed-coated FTO substrate, and the average diameter of NRs is about $45 \mathrm{~nm}$. The well-aligned $\mathrm{ZnO}$ NR arrays could be attributed to the effective growth of $\mathrm{ZnO}$ seeds via the solution method. The one-dimensional (1D) structure of $\mathrm{ZnO}$ NRs supplies good orientation and a large surface area which is favorable for enzyme immobilization. Besides, the SEM image of the ZnO NRs/NRs describes a novel morphology of the small $\mathrm{ZnO}$ NRs grown on the large $\mathrm{ZnO}$ NRs (the average diameter of large ZnO NRs is $800 \mathrm{~nm}$ ). This morphology provides the larger surface area than $\mathrm{ZnO}$ NRs only (see the inset), allowing the higher quantity of enzyme immobilized on the $\mathrm{ZnO} \mathrm{NR} / \mathrm{NR}$ surface with respect to $\mathrm{ZnO}$ NRs. The structure and lattice parameters of $\mathrm{ZnO}$ NRs and $\mathrm{ZnO}$ NRs/NRs are analyzed by X-ray diffraction (XRD). As shown in Figure 1(b), the XRD patterns of $\mathrm{ZnO}$ NRs and $\mathrm{ZnO}$ NRs/NRs show three typical peaks (100), (002), and (101) are located at $2 \theta=33.5^{\circ}, 34.5^{\circ}$, and $37.7^{\circ}$ (JCPDF card no 36-1451), respectively, suggesting the hexagonal wurtzite lattice of $\mathrm{ZnO}$ NRs $[33,34]$. The typical (002) peaks appear at $34.5^{\circ}$, presenting the preferential orientation of NRs along the $c$-axis. In the case of $\mathrm{ZnO}$ NRs, the intensities of other peaks such as (100) and (101) are comparatively lower than that of (002) peaks, implying the fact that the highly oriented along $c$-axis of $\mathrm{ZnO} \mathrm{NRs}$, perpendicular to the plane of the FTO substrate. However, the XRD pattern of $\mathrm{ZnO} \mathrm{NRs} / \mathrm{NRs}$ shows the significant increase in intensities of (100) and (101) peaks with respect to that of the (002) peak. It is because the growth of small $\mathrm{ZnO}$ NRs on the surface of large $\mathrm{ZnO}$ NRs causes the rise of different orientations, e.g, (100) and (101) other than preferential (002) orientation. The XRD result of $\mathrm{ZnO}$ NRs and ZnO NRs/NRs is in agreement with the morphological characterization in SEM images, as shown in Figure 1(a).

3.2. The Activity of Working Electrodes Based on Different Morphologies of $\mathrm{ZnO}$. The FT-IR spectroscopy was used to study the enzyme immobilization on the ZnO NR surface. Figure 2 shows the FT-IR spectra of $\mathrm{ZnO} \mathrm{NRs}$ và $\mathrm{ZnO}$ 


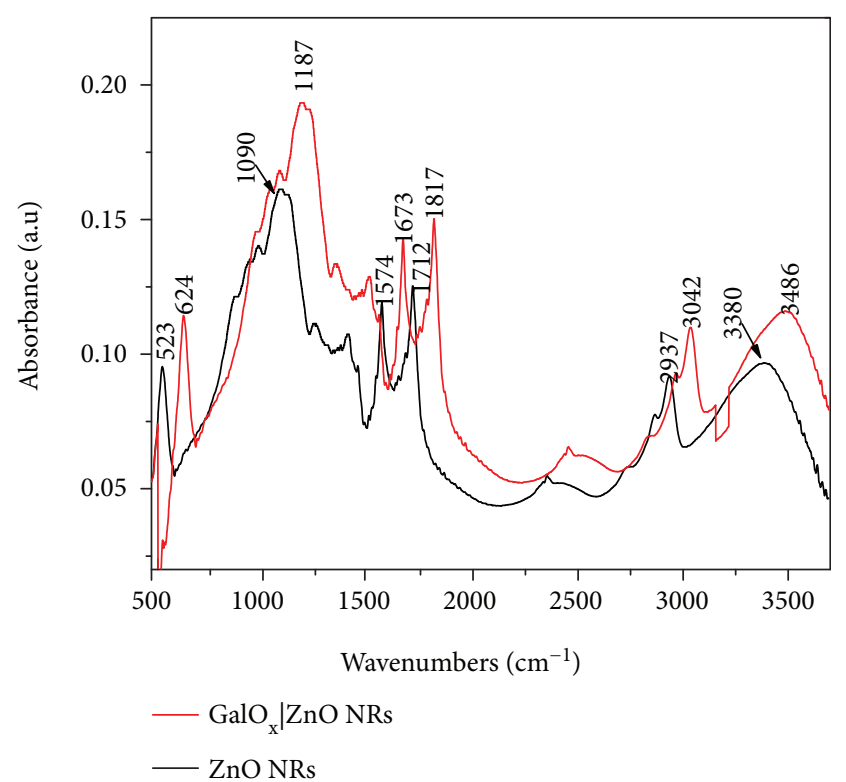

(a)

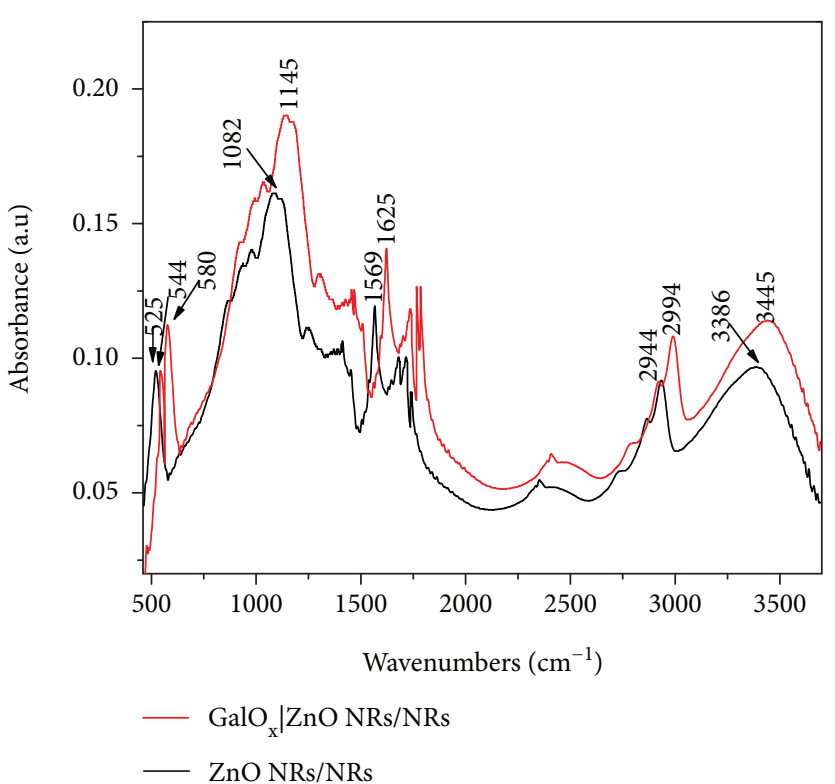

(b)

FIGURE 2: FT-IR spectra of (a) ZnO NRs and (b) ZnO NRs/NRs after and before $\mathrm{GalO}_{\mathrm{x}}$ enzyme immobilization.

NRs/NRs before and after successful $\mathrm{GalO}_{\mathrm{x}}$ enzyme immobilization. Before $\mathrm{GalO}_{\mathrm{x}}$ immobilization, the peaks at $\sim 523-525 \mathrm{~cm}^{-1}$ correlated to stretching modes of $\mathrm{Zn}-\mathrm{O}$ [35], whereas the peaks at $\sim 3386-3380 \mathrm{~cm}^{-1}$ and $1569 \mathrm{~cm}^{-1}$ corresponding to O-H hydroxyl stretching vibration of absorbed water molecules on the surface of the $\mathrm{ZnO}$ NRs are clearly observed in both cases of $\mathrm{ZnO}$ NRs and $\mathrm{ZnO}$ NRs/NRs $[14,36]$. After the $\mathrm{GalO}_{\mathrm{x}}$ immobilization, the peaks at $\sim 525,1082,1569,2944$, and $3386 \mathrm{~cm}^{-1}$ are shifted to the right-hand side, indicating the interaction between the $\mathrm{GalO}_{\mathrm{x}}$ with the surface of the $\mathrm{ZnO}$ NRs. The presence of different peaks in the spectra might be because of impurity in samples [14].

The amount of the $\mathrm{GalO}_{\mathrm{x}}$ enzyme immobilized on the $\mathrm{ZnO}$ surface is calculated by the Bradford method $[35,36]$. The principle of this method relies on the change of maximum absorption wavelength of the Coomassie Brilliant Blue ( $\mathrm{CBB}$ ) reagent in the presence of different bovine serum albumin (BSA) protein concentrations. It is necessary to build the calibration curve before calculating the concentration of $\mathrm{GalO}_{\mathrm{x}}$. To realize this, the different concentrations of BAS protein are added into CBB to form the homogeneous solutions (six samples). The optical density (OD) values of these solutions are measured at the wavelength of $595 \mathrm{~nm}$. It has been reported that without the albumin enzyme, the maximum absorption peak can be obtained at the wavelength of $465 \mathrm{~nm}$ [37]. However, the maximum absorption wavelength changes to $595 \mathrm{~nm}$ when adding albumin to this solution [37]. Therefore, the OD of enzyme solution is measured at $595 \mathrm{~nm}$ wavelength, and this OD value relates to BSA content in solution. By Bradford method, the calibration curve is plotted based on the linear relation of BSA concentrations and OD of enzyme solutions, as shown in Figure 3. Importantly, the

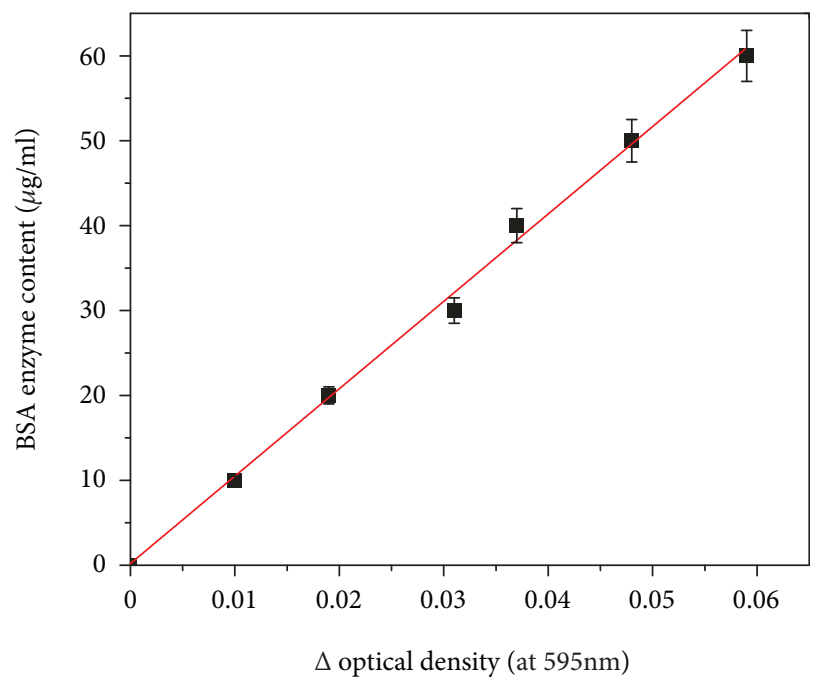

FIgURE 3: The calibration curve of the Bradford method.

calibration curve delivers the standard equation for the calculation of the $\mathrm{GalO}_{\mathrm{x}}$ concentration, as follows:

$$
y=1030.1 x-0.0195
$$

where $y$ is the OD value of the enzyme at $595 \mathrm{~nm}$ and $x$ is the concentration of the enzyme.

Equation (3) expresses the regression line with the regression coefficient of 1030.1 and the intercept of -0.0195 . Thus, the limit of detection (LOD) $[38,39]$ could be estimated as the following:

$$
\mathrm{LOD}=3.3\left(\frac{\mathrm{SE} \sqrt{n}}{\text { Regression coefficient }}\right)
$$




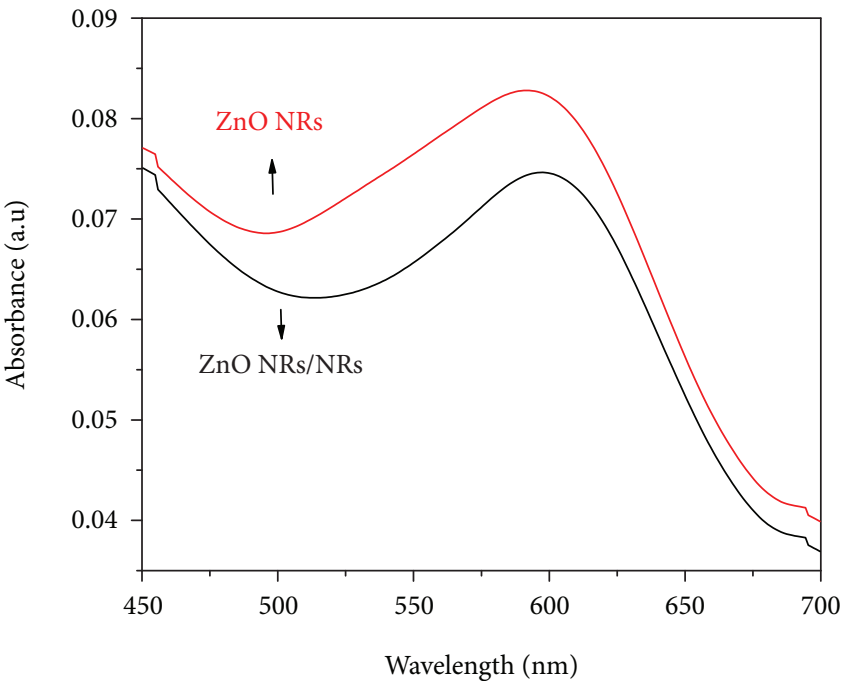

Figure 4: Optical absorption spectra of $\mathrm{GalO}_{\mathrm{x}}$ enzyme solution after the immobilization on ZnO NRs and ZnO NR/NR surfaces.

TABLe 1: Optical density values and the efficiency of the $\mathrm{GalO}_{\mathrm{x}}$ enzyme immobilization on $\mathrm{ZnO}$ NRs and $\mathrm{ZnO}$ NR/NR surfaces.

\begin{tabular}{lcc}
\hline Sample & $\mathrm{GalO}_{\mathrm{x}} \mid \mathrm{ZnO}$ NRs & $\mathrm{GalO} \mathrm{Z}_{\mathrm{X}} \mid \mathrm{ZnO} \mathrm{NRs} / \mathrm{NRs}$ \\
\hline OD value & 0.083 & 0.075 \\
$\Delta \mathrm{OD}$ & 0.022 & 0.014 \\
Enzyme concentration (find out from Bradford standard graph) $(\mu \mathrm{g})$ & 23.1 & 14.5 \\
Enzyme content after the immobilization $(\mu \mathrm{g})$ & 1.155 & 725 \\
Immobilized enzyme content $(\mu \mathrm{g})$ & 845 & 1.275 \\
$H \%$ & 42.25 & 63.75 \\
\hline
\end{tabular}

where LOD is the limit of detection, SE is the standard error of intercept which can be calculated to be $0.889, n$ is the number of measurements, and the value of regression coefficient is 1030.1. Therefore, the value of LOD of the calibration cure (Figure 3 ) is calculated as $5.47 E^{-5}$.

In this study, the BSA protein is replaced by the $\mathrm{GalO}_{\mathrm{x}}$ enzyme. The $\mathrm{GalO}_{\mathrm{x}}$ contents immobilized on $\mathrm{ZnO}$ NRs and $\mathrm{ZnO}$ NRs/NRs are calculated from the OD values of $\mathrm{GalO}_{\mathrm{x}}$ enzyme solutions after 3.5 hours of immobilization. Moreover, the efficiency of the immobilization $(H \%)$ can be found out based on the calibration curve:

$$
H \%=\frac{C_{0}-C_{i}}{C_{0}} \cdot 100 \%
$$

where $C_{0}$ is the concentration of the enzyme at the beginning and $C_{i}$ is the concentration of the enzyme after immobilization.

The OAS spectra of these enzyme solutions in both cases of $\mathrm{ZnO}$ NRs and $\mathrm{ZnO}$ NRs/NRs after the immobilization are acquired in the $450 \mathrm{~nm}$ to $700 \mathrm{~nm}$ wavelength range to obtain the OD values. As shown in Figure 4, the absorption peaks at $\sim 525 \mathrm{~nm}$ associated with the $\mathrm{OD}$ values of enzyme solutions of 0.0745 and 0.827 for $\mathrm{ZnO}$ NRs and $\mathrm{ZnO}$ NRs/NRs, respectively. The efficiency of the $\mathrm{GalO}_{\mathrm{x}}$ immobilization on the $\mathrm{ZnO} \mathrm{NR}$ surface is $42.3 \%$, and it increases to $63.8 \%$ when $\mathrm{GalO}_{\mathrm{x}}$ is immobilized on $\mathrm{ZnO}$
NR/NR surface. It is clearly demonstrated that the amount of the $\mathrm{GalO}_{\mathrm{x}}$ enzyme immobilized on the $\mathrm{ZnO} \mathrm{NR} / \mathrm{NR}$ surface increases because of the high surface to volume ratio of the $\mathrm{ZnO} \mathrm{NR} / \mathrm{NR}$ structure. The $\mathrm{ZnO} \mathrm{NR} / \mathrm{NR}$ structure can be featured on a three-dimensional structure, providing a high surface area for the larger enzyme immobilization with respect to the case of $\mathrm{ZnO}$ NRs only [11, 40]. The OD values and immobilization efficiencies of the $\mathrm{GalO}_{\mathrm{x}}$ enzyme solutions after the immobilization on $\mathrm{ZnO} \mathrm{NRs}$ and $\mathrm{ZnO}$ NRs/NRs were summarized in Table 1.

To examine the catalytic activity of $\mathrm{ZnO}$-based immobilized electrodes, we performed cyclic voltammetry measurement. All experiments are carried out with $\mathrm{GalO}_{\mathrm{x}}$ immobilized $\mathrm{ZnO}$ NRs $\left(\mathrm{GalO}_{\mathrm{x}} \mid \mathrm{ZnO}\right)$ and $\mathrm{GalO}_{\mathrm{x}}$ immobilized $\mathrm{ZnO} \mathrm{NR} / \mathrm{NR}\left(\mathrm{GalO}_{\mathrm{x}} \mid \mathrm{ZnO} \mathrm{NRs} / \mathrm{NRs}\right)$ electrodes at a scan rate of $100 \mathrm{mV} / \mathrm{s}$ with the potential range from $-0.5 \mathrm{~V}$ to $1.0 \mathrm{~V}$. As shown in Figure 5, the cyclic voltammograms $(\mathrm{CV})$ of $\mathrm{GalO}_{\mathrm{x}} \mid \mathrm{ZnO}$ NRs express the oxidation peak at $0.3 \mathrm{~V}$, and the current density is observed about $0.12 \mu \mathrm{A} / \mathrm{mm}^{2}$. On the other hand, in the case of the $\mathrm{GalO}_{\mathrm{x}} \mid \mathrm{ZnO} \mathrm{NR} / \mathrm{NR}$ electrode, this peak appears at $0.25 \mathrm{~V}$ with the enhanced value of current density $0.18 \mu \mathrm{A} / \mathrm{mm}^{2}$ with respect to that of the $\mathrm{GalO}_{\mathrm{x}} \mid \mathrm{ZnO}$ NR electrode. The presence of these two oxidation peaks indicates the oxidation of $\mathrm{Gal}$ with the $\mathrm{GalO}_{\mathrm{x}}$ catalyst assist, which has been well explained by equations (1) and (2) [13]. Moreover, the potential difference between these two peaks $(0.3 \mathrm{~V}$ 


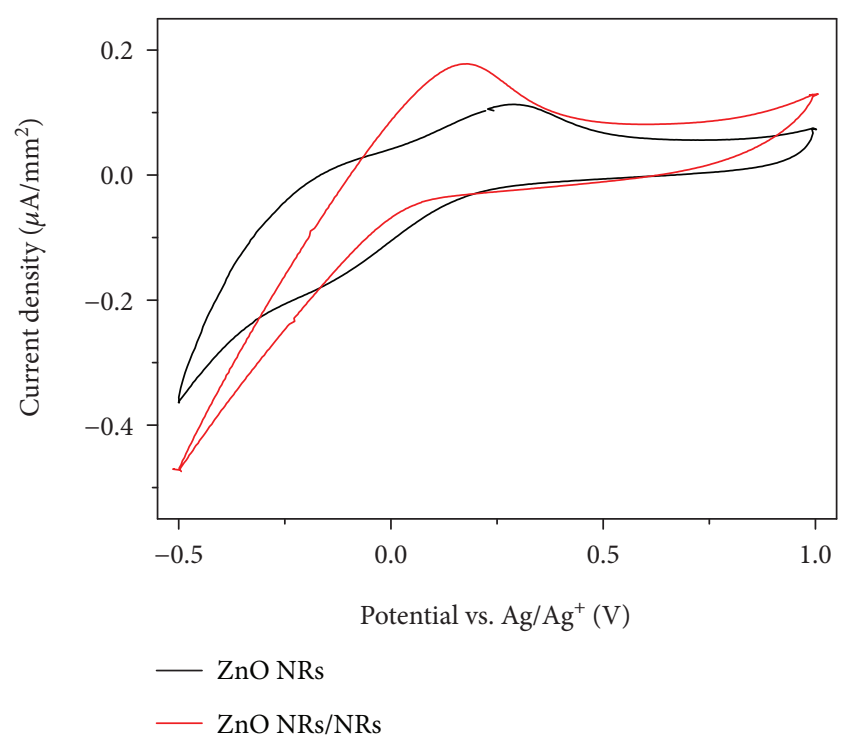

FIgURE 5: The cyclic voltammograms of $\mathrm{GalO}_{\mathrm{x}} \mid \mathrm{ZnO} \mathrm{NRs}$ and $\mathrm{GalO}_{\mathrm{x}} \mid \mathrm{ZnO} \mathrm{NR} / \mathrm{NR}$ electrodes in $200 \mathrm{mM}$ galactose solution at a scan rate of $100 \mathrm{mV} / \mathrm{s}$.

and $0.25 \mathrm{~V}$ ) may be since the different contact resistances caused the difference of interface contact between $\mathrm{GalO}_{\mathrm{x}}$ and $\mathrm{ZnO}$ surfaces. Importantly, the higher current density of the $\mathrm{GalO}_{\mathrm{x}} \mid \mathrm{ZnO} \mathrm{NR} / \mathrm{NR}$ electrode $\left(0.18 \mu \mathrm{A} / \mathrm{mm}^{2}\right)$ with respect to the $\mathrm{GalO}_{\mathrm{x}} \mid \mathrm{ZnO} \mathrm{NR}\left(0.12 \mu \mathrm{A} / \mathrm{mm}^{2}\right)$ one indicates that more oxidation reactions are taking place on the surface of the $\mathrm{GalO}_{\mathrm{x}} \mid \mathrm{ZnO} \mathrm{NR} / \mathrm{NR}$ electrode than that of $\mathrm{GalO}_{\mathrm{x}} \mid \mathrm{ZnO}$ NRs. This result confirms the novel morphology of $\mathrm{ZnO}$ NRs/NRs (see SEM image in Figure 1(a)), providing the high surface to volume ratio to increase the amount of the $\mathrm{GalO}_{\mathrm{x}}$ enzyme immobilized on the $\mathrm{ZnO}$ surface (as calculated in Table 1). The high concentration of $\mathrm{GalO}_{\mathrm{x}}$ promotes the oxidation of Gal by its catalytic capability, promoting the electron transfer process (see equations (1) and (2)) of reaction which causes the enhancement of the peak current density.

The various cyclic voltammetry measurements of $\mathrm{GalO}_{\mathrm{x}} \mid \mathrm{ZnO}$ NRs and $\mathrm{GalO}_{\mathrm{x}} \mid \mathrm{ZnO}$ NR electrodes in different concentrations of Gal solution, ranging from $40 \mathrm{mM}$ to $230 \mathrm{mM}$, are carried out to evaluate the performance of these biosensors. The current densities delivered from the oxidation peaks in the $\mathrm{CV}$ results of $\mathrm{GalO}_{\mathrm{x}} \mid \mathrm{ZnO}$ NRs and $\mathrm{GalO}_{\mathrm{x}} \mid \mathrm{ZnO} \mathrm{NR} / \mathrm{NR}$ electrodes exhibit the linear correlation with the Gal concentrations, as illustrated in Figure 6. In the case of the $\mathrm{GalO}_{\mathrm{x}} \mid \mathrm{ZnO} \mathrm{NR}$ electrode, the average current density linearly increases with the increasing of Gal concentration. This linear correlation is expressed by equation $y=0.0142 x+9.3511$, as depicted in the black line in Figure 6. On the other hand, this linear correlation, see the red line in Figure 6, is associated with equation $y=$ $0.0369 x+10.063$ in the case of $\mathrm{GalO}_{\mathrm{x}} \mid \mathrm{ZnO}$ NRs/NRs. The values of regression coefficients are calculated to be 0.0139 and 0.0364 for $\mathrm{GalO}_{\mathrm{x}} \mid \mathrm{ZnO} \mathrm{NRs}$ and $\mathrm{GalO}_{\mathrm{x}} \mid \mathrm{ZnO}$ NRs/NRs, respectively. Besides, according to equation (4), the LODs are calculated to be $105.62 \mathrm{mM}$ and $54.742 \mathrm{mM}$ for $\mathrm{GalO}_{\mathrm{x}} \mid \mathrm{ZnO}$ NRs and $\mathrm{GalO}_{\mathrm{x}} \mid \mathrm{ZnO}$ NRs/NRs, respectively. These results imply the better sensitivity of the $\mathrm{GalO}_{\mathrm{x}} \mid \mathrm{ZnO}$

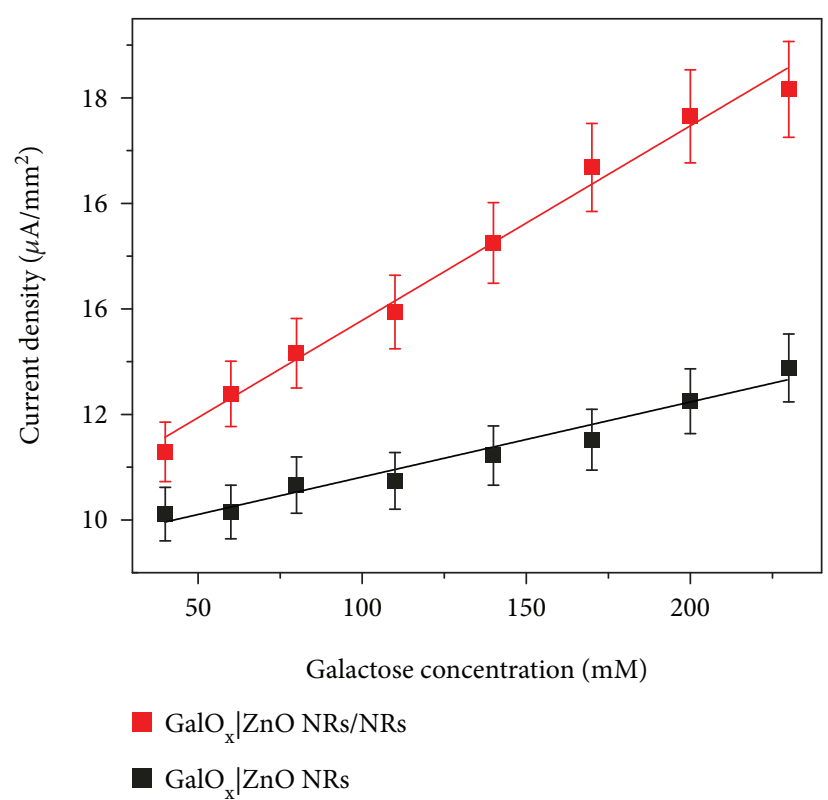

FIGURE 6: The plots of current density vs. the Gal concentration of $\mathrm{GalO}_{\mathrm{x}} \mid \mathrm{ZnO} \mathrm{NRs} / \mathrm{NRs}$ and $\mathrm{GalO}_{\mathrm{x}} \mid \mathrm{ZnO}$ NRs.

NR/NR electrode with respect to the $\mathrm{GalO}_{\mathrm{x}} \mid \mathrm{ZnO} \mathrm{NR}$ one at the elevated concentration of Gal.

Also, with the increased concentration of $\mathrm{GalO}_{\mathrm{x}}$ from $40 \mathrm{mM}$ to $230 \mathrm{mM}$, the current density of the $\mathrm{GalO}_{\mathrm{x}} \mid \mathrm{ZnO}$ NR electrode increases from $10.11 \mu \mathrm{A} / \mathrm{mm}^{2}$ to $12.88 \mu \mathrm{A} / \mathrm{mm}^{2}$, implying the increase of $27.40 \%$. Meanwhile, the current density of the $\mathrm{GalO}_{\mathrm{x}} \mid \mathrm{ZnO} \mathrm{NR} / \mathrm{NR}$ electrode increases from $11.30 \mu \mathrm{A} / \mathrm{mm}^{2}$ to $18.16 \mu \mathrm{A} / \mathrm{mm}^{2}$, corresponding to the increment of $60.7 \%$. This demonstrates that the sensitivity of the $\mathrm{GalO}_{\mathrm{x}} \mid \mathrm{ZnO} \mathrm{NR} / \mathrm{NR}$ electrode is superior to that of the $\mathrm{GalO}_{\mathrm{x}} \mid \mathrm{ZnO}$ NR one. These results come from the novel structure of $\mathrm{ZnO}$ NRs/NRs with a high surface area, providing the increase in the amount of $\mathrm{GalO}_{\mathrm{x}}$ enzyme immobilization with respect to the $\mathrm{ZnO} \mathrm{NR}$ structure.

\section{Conclusion}

A novel nanostructure of $\mathrm{ZnO}$ NRs/NRs has been successfully synthesized via the solution method. This structure enables the excellent $\mathrm{GalO}_{\mathrm{x}}$ immobilization since its special morphology provides a high surface area to volume ratio, therefore enhancing the performance of Gal biosensor. Remarkably, the electrochemical response acquired from $\mathrm{CV}$ analysis shows that the current density of the $\mathrm{GalO}_{\mathrm{x}} \mid \mathrm{ZnO} \mathrm{NR} / \mathrm{NR}\left(0.18 \mu \mathrm{A} / \mathrm{mm}^{2}\right)$ electrode is higher than that of the $\mathrm{GalO}_{\mathrm{x}} \mid \mathrm{ZnO}$ NR electrode $\left(0.12 \mu \mathrm{A} / \mathrm{mm}^{2}\right)$. Moreover, as the concentration of Gal solution increases from $40 \mathrm{mM}$ to $230 \mathrm{mM}$, the sensitivity of the $\mathrm{GalO}_{\mathrm{x}} \mathrm{ZnO}$ NR/NR electrode increases $60.7 \%$, which is much higher than that of the $\mathrm{GalO}_{\mathrm{x}} \mid \mathrm{ZnO} \mathrm{NR}$ one (27.4\%). Thus, the novel structure of $\mathrm{ZnO} \mathrm{NRs} / \mathrm{NRs}$ is opening a promising research direction in material synthesis via the facile, lowcost, and environmentally friendly method, for highperformance biosensors. 


\section{Data Availability}

(1) The data supporting the findings (figures and table) of this study are available within the article. (2) The data that support the findings of this study (figures and table) are available from the corresponding author (Dr. Tran Viet Cuong) upon reasonable request.

\section{Conflicts of Interest}

The authors declare that they have no conflicts of interest.

\section{Acknowledgments}

This work was supported by the Basic Research Program through the National Research Foundation of Korea (NRF) funded by the Ministry of Education (NRF-2017R1D1A3B03 030758) and (NRF-2016R1D1A1A09919950).

\section{References}

[1] P. B. Acosta and K. C. Gross, "Hidden sources of galactose in the environment," European Journal of Pediatrics, vol. 154, no. S2, pp. S87-S92, 1995.

[2] A. I. Coelho, G. T. Berry, and M. E. Rubio-Gozalbo, "Galactose metabolism and health," Current Opinion in Clinical Nutrition and Metabolic Care, vol. 18, no. 4, pp. 422-427, 2015.

[3] G. T. Berry, "Disorders of galactose metabolism," in Rosenberg's Molecular and Genetic Basis of Neurological and Psychiatric Disease (Fifth Edition), pp. 615-626, Inborn Metabolic Diseases, Springer, 2015.

[4] A. M. Bosch, "Classic galactosemia: dietary dilemmas," Journal of Inherited Metabolic Disease, vol. 34, no. 2, pp. 257-260, 2011.

[5] S. S. Gropper, K. C. Gross, and S. J. Olds, "Galactose content of selected fruit and vegetable baby foods: implications for infants on galactose-restricted diets," Journal of the American Dietetic Association, vol. 93, no. 3, pp. 328-330, 1993.

[6] S. G. Kahler and M. C. Fahey, "Metabolic disorders and mental retardation," American Journal of Medical Genetics, vol. 117C, no. 1, pp. 31-41, 2003.

[7] G. T. Berry, "Galactosemia and amenorrhea in the adolescent," Annals of the New York Academy of Sciences, vol. 1135, no. 1, pp. 112-117, 2008.

[8] J. Tkáč, P. Gemeiner, and E. Šturdík, "Rapid and sensitive galactose oxidase-peroxidase biosensor for galactose detection with prolonged stability," Biotechnology Techniques, vol. 13, no. 12, pp. 931-936, 1999.

[9] P. Kanyong, R. M. Pemberton, S. K. Jackson, and J. P. Hart, "Development of an amperometric screen-printed galactose biosensor for serum analysis," Analytical Biochemistry, vol. 435, no. 2, pp. 114-119, 2013.

[10] P. Kanyong, G. Hughes, R. M. Pemberton, S. K. Jackson, and J. P. Hart, "Amperometric screen-printed galactose biosensor for cell toxicity applications," Analytical Letters, vol. 49, no. 2, pp. 236-244, 2016.

[11] P. Kanyong, F. D. Krampa, Y. Aniweh, and G. A. Awandare, "Enzyme-based amperometric galactose biosensors: a review," Microchimica Acta, vol. 184, no. 10, pp. 3663-3671, 2017.

[12] W. Shi and Z. Ma, "Amperometric glucose biosensor based on a triangular silver nanoprisms/chitosan composite film as immobilization matrix," Biosensors \& Bioelectronics, vol. 26, no. 3, pp. 1098-1103, 2010.

[13] M. Sharma and M. Sharma, "Amperometric galactose biosensor based on silver nanoparticles/carboxylated multiwalled carbon nanotubes/polyaninine composite film," International Journal of Recent Scientific Research, vol. 8, no. 8, pp. 1897618983, 2017.

[14] K. Khun, Z. H. Ibupoto, O. Nur, and M. Willander, "Development of galactose biosensor based on functionalized $\mathrm{ZnO}$ nanorods with galactose oxidase," Journal of Sensors, vol. 2012, Article ID 696247, 7 pages, 2012.

[15] J. M. Pingarrón, P. Yáñez-Sedeño, and A. González-Cortés, "Gold nanoparticle-based electrochemical biosensors," Electrochimica Acta, vol. 53, no. 19, pp. 5848-5866, 2008.

[16] M. Vidotti, R. F. Carvalhal, R. K. Mendes, D. C. M. Ferreira, and L. T. Kubota, "Biosensors based on gold nanostructures," Journal of the Brazilian Chemical Society, vol. 22, no. 1, pp. 3-20, 2011.

[17] Y. Li, H. J. Schluesener, and S. Xu, "Gold nanoparticle-based biosensors," Gold Bulletin, vol. 43, no. 1, pp. 29-41, 2010.

[18] Y. Zhang, Y. Liu, J. He, P. Pang, Y. Gao, and Q. Hu, "Electrochemical behavior of caffeic acid assayed with gold nanoparticles/graphene nanosheets modified glassy carbon electrode," Electroanalysis, vol. 25, no. 5, pp. 1230-1236, 2013.

[19] F. Zhang and M. P. Srinivasan, "Multilayered gold-nanoparticle/polyimide composite thin film through layer-by-layer assembly," Langmuir, vol. 23, no. 20, pp. 10102-10108, 2007.

[20] S. K. Sharma, Suman, C. S. Pundir, N. Sehgal, and A. Kumar, "Galactose sensor based on galactose oxidase immobilized in polyvinyl formal," Sensors and Actuators B: Chemical, vol. 119, no. 1, pp. 15-19, 2006.

[21] T. Yao and K. Takashima, "Amperometric biosensor with a composite membrane of sol-gel derived enzyme film and electrochemically generated poly(1,2-diaminobenzene) film," Biosensors \& Bioelectronics, vol. 13, no. 1, pp. 67-73, 1998.

[22] E. Ekinci and A. Paşahan, "Poly (4-methoxyphenol) film as a galactose-sensing material," European Polymer Journal, vol. 40, no. 8, pp. 1605-1608, 2004.

[23] S. J. Cho, H. B. Noh, M. S. Won, C. H. Cho, K. B. Kim, and Y. B. Shim, "A selective glucose sensor based on direct oxidation on a bimetal catalyst with a molecular imprinted polymer," Biosensors \& Bioelectronics, vol. 99, pp. 471-478, 2018.

[24] D. Das, D. M. Kim, D. S. Park, and Y. B. Shim, “A glucose sensor based on an aminophenyl boronic acid bonded conducting polymer," Electroanalysis, vol. 23, no. 9, pp. 2036-2041, 2011.

[25] Y. Zhang, M. K. Ram, E. K. Stefanakos, and D. Y. Goswami, "Synthesis, characterization, and applications of $\mathrm{ZnO}$ nanowires," Journal of Nanomaterials, vol. 2012, Article ID 624520, 22 pages, 2012.

[26] Z. Zhao, W. Lei, X. Zhang, B. Wang, and H. Jiang, “ZnO-based amperometric enzyme biosensors," Sensors, vol. 10, no. 2, pp. 1216-1231, 2010.

[27] Z. Yang, X. L. Zong, Z. Ye, B. Zhao, Q. L. Wang, and P. Wang, "The application of complex multiple forklike $\mathrm{ZnO}$ nanostructures to rapid and ultrahigh sensitive hydrogen peroxide biosensors," Biomaterials, vol. 31, no. 29, pp. 7534-7541, 2010.

[28] Z. Fan and J. G. Lu, "Zinc oxide nanostructures: synthesis and properties," Journal of Nanoscience and Nanotechnology, vol. 5, no. 10, pp. 1561-1573, 2005.

[29] R. Ahmad, M. S. Ahn, and Y. B. Hahn, "ZnO nanorods array based field-effect transistor biosensor for phosphate detection," 
Journal of Colloid and Interface Science, vol. 498, pp. 292-297, 2017.

[30] A. Wei, X. W. Sun, J. X. Wang et al., "Enzymatic glucose biosensor based on $\mathrm{ZnO}$ nanorod array grown by hydrothermal decomposition," Applied Physics Letters, vol. 89, no. 12, p. $123902,2006$.

[31] X. Liu, Q. Hu, Q. Wu, W. Zhang, Z. Fang, and Q. Xie, “Aligned $\mathrm{ZnO}$ nanorods: a useful film to fabricate amperometric glucose biosensor," Colloids and Surfaces B: Biointerfaces, vol. 74, no. 1, pp. 154-158, 2009.

[32] N. Palomera, M. Balaguera, S. K. Arya et al., "Zinc oxide nanorod films for electrochemical urea biosensor," Materials Research Society Symposium Proceedings, vol. 1355, 2011.

[33] S. N. Sarangi, S. Nozaki, and S. N. Sahu, "ZnO nanorod-based non-enzymatic optical glucose biosensor," Journal of Biomedical Nanotechnology, vol. 11, no. 6, pp. 988-996, 2015.

[34] E. Arca, K. Fleischer, and I. V. Shvets, "Influence of the precursors and chemical composition of the solution on the properties of $\mathrm{ZnO}$ thin films grown by spray pyrolysis," Journal of Physical Chemistry C, vol. 113, no. 50, pp. 21074-21081, 2009.

[35] R. Hong, T. Pan, J. Qian, and H. Li, "Synthesis and surface modification of $\mathrm{ZnO}$ nanoparticles," Chemical Engineering Journal, vol. 119, no. 2-3, pp. 71-81, 2006.

[36] J.-J. Dong, C. Y. Zhen, H. Y. Hao et al., "Controllable synthesis of $\mathrm{ZnO}$ nanostructures on the Si substrate by a hydrothermal route," Nanoscale Research Letters, vol. 8, no. 1, p. 378, 2013.

[37] C. V. Sapan, R. L. Lundblad, and N. C. Price, "Colorimetric protein assay techniques," Biotechnology and Applied Biochemistry, vol. 29, no. 2, pp. 99-108, 1999.

[38] D. A. Armbruster and T. Pry, "Limit of blank, limit of detection and limit of quantitation," The Clinical Biochemist Reviews, vol. 29, article S49, Supplement 1, 2008.

[39] G. L. Long and J. D. Winefordner, "Limit of detection a closer look at the IUPAC definition," Analytical Chemistry, vol. 55, no. 7, pp. 712A-724A, 1983.

[40] X. Duan, Y. Li, N. K. Rajan, D. A. Routenberg, Y. Modis, and M. A. Reed, "Quantification of the affinities and kinetics of protein interactions using silicon nanowire biosensors," Nature Nanotechnology, vol. 7, no. 6, pp. 401-407, 2012. 


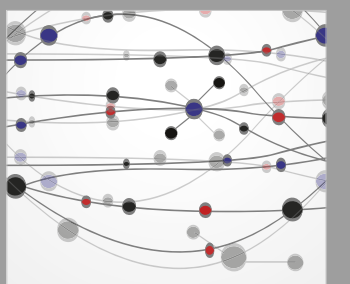

The Scientific World Journal
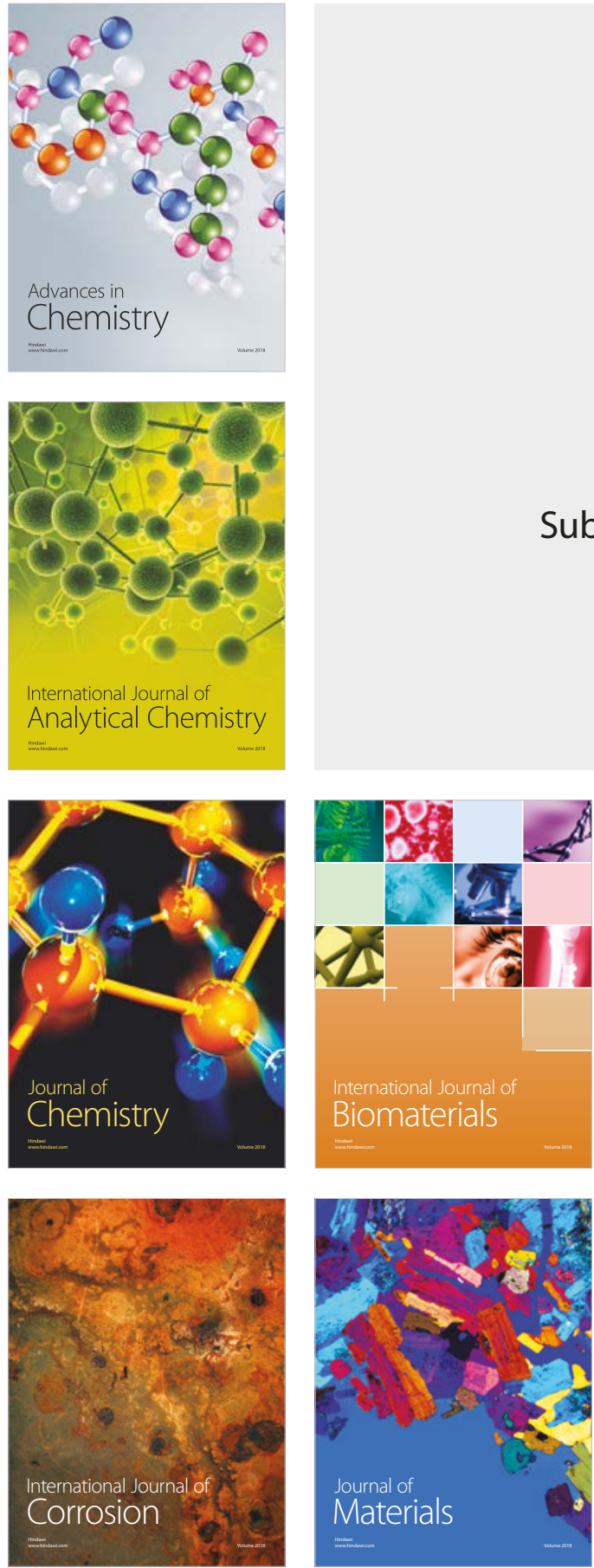

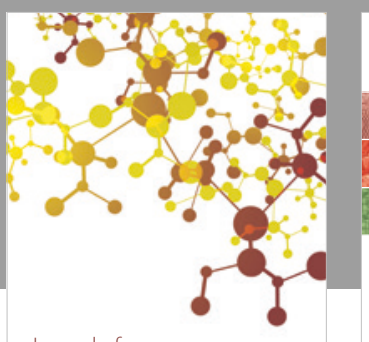

Journal of

Applied Chemistry
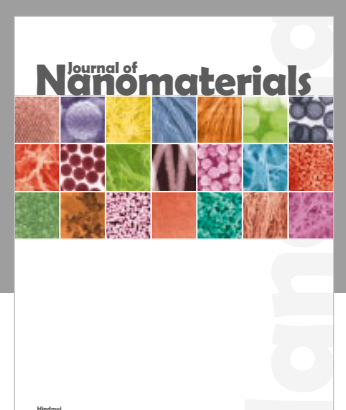

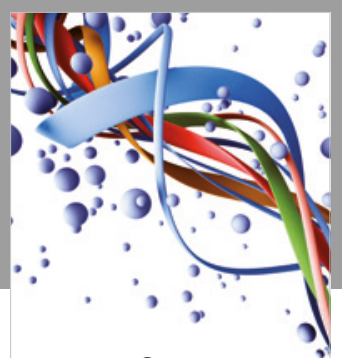

Scientifica

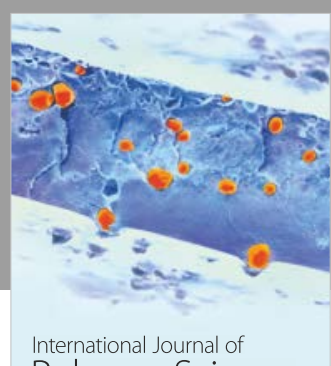

Polymer Science

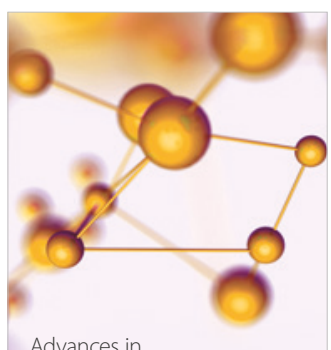

Physical Chemistry
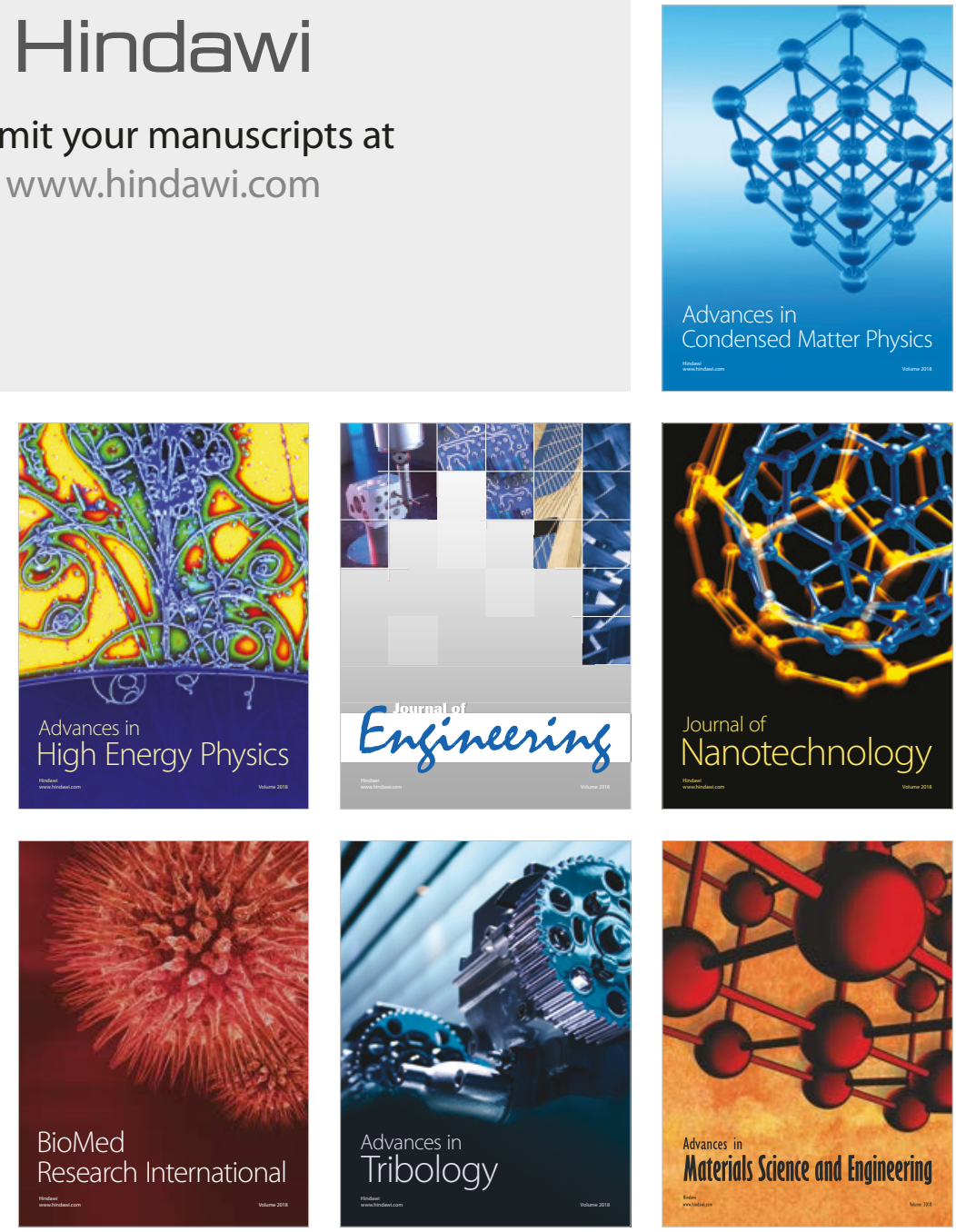